\title{
Policy is what happens while you're busy doing something else: introduction to special issue on "language" indexing higher education policy
}

\author{
Taina Saarinen ${ }^{1}$
}

Published online: 23 March 2016

(C) Springer Science+Business Media Dordrecht 2016

\section{Position of "language" in higher education policy research}

Traditionally, language has had three functions in higher education. It has been seen as a medium of teaching; as a means of archiving knowledge in different text depositories like books and libraries; and as an object of theoretical study (Brumfit 2004, 164). Brumfit's typology acknowledges the fact that language somehow crosses the everyday experience of everyone working, studying or otherwise engaged at universities-in other words, in knowledge production.

In recent years, however, two major trends in higher education policies have challenged Brumfit's classification and called for attention to language in a new way: internationalization and globalization policies on the one hand, and knowledge society and knowledge economy policies on the other. Both internationalization (with its connotations to intercultural linguistic contact and communication) and knowledge economy or knowledge society (composed of the informational and cultural contents of immaterial labour; Williams 2010) are highly language-intensive phenomena. This highlights the need to rethink the role of language ${ }^{1}$ in when practices and policies of higher education are studied.

Empirically, language in higher education policy research has been studied mainly in the context of internationalization, in the frame of Brumfit's first category of language as a medium of teaching. In Higher Education, 35 articles have in the years 2000-2014 somehow focussed on language. However, majority of these lack the policy dimension, and deal with English language learning in the context of internationalization, and the (usually

${ }^{1}$ By Language, I do not mean only the formal symbolic communication systems used by different groups of people (often described as separate languages such as English, Dari or Latin), but as a functional societal practice that has a role in knowledge construction.

Taina Saarinen

taina.m.saarinen@jyu.fi

1 Jyväskylä, Finland 
classroom) effects of using some lingua franca (mostly English) as language of instruction (see, for instance, Torres-Olave 2012; Byun et al. 2011; Sherry et al. 2010). In a rare example of a more policy-oriented article that considers language in higher education policies, Marginson (2006) analyses higher education as a globally competitive and asymmetrically resourced market, dominated by dynamics of the English language. Ultimately, however, this is also a question of language (in this case English) as a medium of teaching; i.e. Brumfit's first category. The other categories of language in archiving knowledge and language as object of theoretical research have not been prominent in higher education research.

Elsewhere, language in the context of higher education has mostly been dealt with from the perspective of use of English or different learning perspectives (for Nordic examples see Airey 2009; Hellekjær 2010; Salö 2010; for others, see Coleman 2006; Alexander 2008, or articles in the recently founded journal Language Learning in Higher Education, published by de Gruyter). Phillipson discusses in his extensive production questions of linguistic imperialism, also in higher education (see for example Phillipson 2009). While his approach is definitely political, he does not explicitly deal with higher education policies. Hughes (2008) discusses "language" mainly from an economic commodity perspective in higher education, discussing particularly the role of English and then advantage of English-speaking countries in the international degree programme markets. In knowledge economy studies, Williams' 2010 work is one of the rare attempts at linking language, knowledge economy and culture.

Recent sociological studies on cultural and social diversification emphasize the role of language in post-industrial networked societies, characterized by diversified forms of immigration (see Vertovec 2007 on the concept of super-diversity), more language-intensive working life (see Heller 2011, and the shift from workforce to wordforce), and new communication and information technologies (Castells 2000). However, while we would intuitively expect language to feature more prominently on the theoretical level in research dealing with internationalization and knowledge society (both highly language-intensive activities), this does not seem to be the case empirically (Saarinen 2012).

This special issue on Language indexing higher education policy expands Brumfit's view of the role of language by acknowledging the language-related theoretical, methodological and empirical inputs on higher education policy research, exerted by developments related to internationalization. In other words, we will analyse the ways in which a look at language illuminates our understanding of higher education policy.

A recent example of new attention towards language as depicting higher education policy is Kuteeva and Airey's (2014) analysis of language and knowledge production in higher education. Kuteeva and Airey point towards the inadequacy of "one-size-fits-all" language policy measures in dealing with the disciplinary-specific needs of universities.

I will next look in more detail into the role of internationalization and knowledge society policies within higher education as putting pressure on acknowledging language in higher education policy.

\section{Language indexing national and international roles of higher education}

Increasing focus on policies of "internationalization", "knowledge society" and "knowledge economy" within higher education (see for instance Välimaa and Hoffman 2008 for a discussion on the discourses of knowledge society; and Williams 2010 on the role of 
language in knowledge economy) have caused changes in degree structures and evaluation systems, as a greater deal of political transparency has been called for because of demands of mobility (of people, goods, money and ideas). Simultaneously, political demands for increased internationalization have challenged the traditional understanding of higher education as national (see articles in this special issue). Several reforms have recently taken place from the point of view of the "international attractiveness" of higher education.

This creates an apparent paradox, as universities as institutions have been defined both as intensely international and inherently national. This is true in that universities are international in as much as their knowledge base is international: scientific disciplines and research have an international (or at least universal) basis (Haapakorpi and Saarinen 2014; see Clark 1983 for a discussion of on the fundamentals of disciplines; Becher and Trowler 2001 on the nature of disciplines). However, universities are also strongly national institutions with a role in nation building particularly in the first half of the nineteenth century (Anderson 1991; on Finland, see Välimaa 2012; on Denmark, see Mortensen and Haberland 2012), as first periods of massification of higher education in the 1800s broke the academic independence of universities and tied them more closely to the nation states and their knowledge needs. In other words, universities are as much results of their disciplinary internationalization as their organizational nationalism.

As Williams $(2010,10)$ points out, at the core of "knowledge economy" lies immaterial labour (cf. Heller's wordforce mentioned above), which, in turn, is composed by informational and culturally construed contents; in other words, highly language-intensive activities. Simultaneously, internationalization and processes related to it challenge higher education dynamics from a series of viewpoints. Not only are non-Anglophone universities (Nordic universities typically) resorting to producing English-medium programmes and tuition at universities and polytechnics to overcome what Hughes calls the "Anglophone asymmetry" in the increasingly international student markets (see Hughes 2008), where four Englishspeaking countries provide $50 \%$ of programmes that involve study abroad. These developments also challenge the national, public service function of Nordic higher education (see Välimaa 2005 for an historical and social dynamics view into Finnish higher education) in stressing the global research, teaching and societal responsibilities and roles of universities.

A focus on the political role of language helps make visible the tensions between the national and nation-state-oriented roles of higher education on the one hand and international and global roles on the other. Language requirements in higher education can be used as a form of high modern governance, creating hierarchies of domestic and international staff and students (Saarinen and Nikula 2013; Saarinen 2014). Promoting the English language in higher education while simultaneously presenting protectionist concerns about the competitiveness of national higher education systems may, however, suggest a break in the national romantic links between nation and language (Saarinen 2014).

Next, I will discuss the premises of multi-sited and multi-layered policy, which frames this special issue.

\section{Policy is what happens when you're busy doing other things: higher education policy as multi-sited}

Until recently, structural approaches (i.e. approaches focusing on policy structures at local, national, regional and international level) appear to have dominated higher education policy research (Saarinen and Ursin 2012). Focusing on structural approaches in higher 
education policy is linked to a major trend in European higher education policy research; i.e. the study of policy reforms and their implementation (Välimaa 2008). Policy reforms such as New Public Management, assessment, and internationalization policies have invited countless studies into their implementation (Teichler 2005).

What is also only emerging in research is an understanding of the multi-sitedness of policy formation. The links between the different levels (vertical) and different policy sectors and actors (horizontal) have remained largely opaque. Research that focuses on formal policies and policy structures (be they at macro-, meso- or micro-policies, or local, national or global levels of action) fails to take into account the temporally and spatially fluctuating networked contacts between different actors (human or institutional), and the dynamics between those contacts.

The amount of research focusing on local, national and global reforms shows the appeal of the focus on observable structures and the dichotomies such as macro-micro or globallocal that the structures invite. These dichotomies make different policy levels analytically visible and understandable (for a similar discussion of language policies, see Hult 2010, following Blommaert 2007). However, recent research in higher education policy has demonstrated that phenomena like "globalization" and "internationalization" are not selfevident layers that can be added on top of national and local structures of higher education policy. Rather, they challenge our understanding of the functioning of those apparently structured systems (Saarinen 2015).

Criticism of a linear and dichotomous policy view has been presented elsewhere as well (see for instance Marginson and Rhoades 2002 and their glonacal agency heuristic). Dale and Robertson (2009) have criticized the view where globalization and internationalization are seen as merely adding another level to the structures of education policy. Rather, these developments should challenge our understanding of the mechanisms at work behind these apparently neatly linearly and hierarchically structured dichotomous levels of globalnational-local. Dale and Robertson point out that this kind of a limited view is behind three intertwined theoretical and methodological problems or fallacies in comparative (education) research: methodological nationalism; methodological statism; and methodological educationism. By this, they criticize the tendency to see "nation", "state" and "education" as something fixed and absolute, and point out that it has taken a phenomenon like "globalization" to expose these "isms" in comparative educational research.

How, then, can we approach the fluid and nonlinear higher education policies? The "linguistic turn" in social sciences (Fairclough 1992) has made language methodologically visible in higher education policy research in recent years (see Saarinen 2008). As a consequence, language has been understood as having a functional role in construing our understanding of the political realities and policy formation.

Shifting our view from policy as a linear top-down design and implementation of decisions towards a fluid, networked and multi-layered process has already changed the research scene, which is made more complex by national systems and policies acting in networked ways with local and supranational actors and practices (Ball 2012). Policies are, largely, discursively construed by persuasive rather than authoritative means (Becher and Kogan 1992; Saarinen 2008). We appear to be witnessing a lessening of interest in social structures (Castells 2000; see Ball 2012, 5) still so predominant in higher education policy studies (cf. Saarinen and Ursin 2012) and increased interest in networked actors. What we are witnessing, in other words, is the emergence of higher education policy as temporal and spatial (or multi-sited, see Marcus 1995; Halonen et al. 2015). The complexity of global policy formation is mirrored also on the national and local level, as discussed in the previous chapter. 
As a consequence of the discrepancies between how policies are construed in practice as networked and soft, and how they are conceptualized in research as structural and dichotomous, policies often appear contradictory (as the policy measures of the different actors appear contradictory), and unsuccessful and haphazard (as the new kinds of mechanisms hide the policy making process) (Saarinen 2015). This produces the appearance of "policy happening while you're busy doing other things", to paraphrase a quotation often attributed to John Lennon. The "things" that happen in policy implementation are not "distractions" and "disturbances" in the policy; they are policy in its networked, fuzzy, and spatially and temporally construed - in other words, multi-sited and multilayered ways (see Saarinen 2015; Halonen et al. 2015).

To summarize, in a situation where policies are construed temporally and spatially in fluid and flux settings (i.e. when policies are multi-sited), policies can no longer be studied as rational plans and their equally rational implementation (see Saarinen and Välimaa 2012). Rather, we need to see policy taking place at different levels and in different times, being formulated as it is enacted. While dichotomies such as macro-micro, discoursespractices, structures-agents, ideals-realities are necessary in making policy issues visible and understandable, they also tend to (over-)simplify the multi-sited issues they represent (see Hult 2010), and turn our focus back on the structural. If we take the above description of the changes in higher education policy as a starting point, a central theoretical and methodological challenge for research will be to overcome these dichotomies and include in the analysis an integration and critique of these concepts (see Halonen et al. 2015).

In this special issue, we will look beyond these structural and reform-oriented views into a multi-layered higher education policy. Following for instance Hornberger and Johnson (2007) and their onion metaphor of language policies, we find the description of policy as a multi-layered, multi-spatial and locally informed process necessary in conceptualizing higher education (Saarinen 2015).

\section{Articles in this special issue}

In this special issue, all articles somehow deal with the thematic of multi-sited and multilayered higher education policy, where language has a role in the construction of that policy. Empirically, the articles investigate language in working life, language policy formulation, the relationship between language policies and internationalization, and language policies in the context of the Bologna process. The common theme in all the articles is the intertwined links between different policies and policy levels that may either support or contradict each other.

John Airey, Karen Lauridsen, Anne Räsänen, Linus Salö and Vera Schwach review the effects of English-medium instruction (EMI) on different disciplines and different organizations in the Nordic countries, discussing particularly the language policy implications of EMI. They discuss the ontological implications of language policies and encourage a language policy formation that acknowledges the different disciplinary and organizational requirements when drafting institutional language policies.

Ragnhild Ljosland (published in a previous issue of Higher Education in 2015 but a part of this special issue) analyses higher education policy making as a multi-layered and multiagency activity in a Norwegian context, acknowledging the multi-sited nature of higher education policy making in her empirical analysis of language policy formation in a context of internationalization of higher education. 
Anne Fabricius, Janus Mortensen and Hartmut Haberland problematize the three paradoxes made apparent by internationalization of Danish higher education. They analyse the assumed links between internationalization and linguistic pluralism, intercultural understanding, and competitiveness. They deconstruct these paradoxes into a critique of the concept of parallel language policy promoted in Nordic countries and show how internationalization, in effect, does not necessarily lead to linguistic pluralism, increased intercultural understanding and increased competitiveness.

Glenn Ole Hellekjar and Tone Fairway (published in a previous issue of Higher Education in 2015 but a part of this special issue) analyse the potential pedagogical implications of English language needs of government employees. They go back from the needs of ministries' language needs and English training (see Brumfit) to a pedagogical need to integrate language and content teaching, but with the goal of increasing English skills.

Taina Saarinen and Peppi Taalas close the special issue with an analysis of language policy formation in Nordic higher education in different levels and by different actors on the national and local level. They discuss the relationships between legislative and strategic needs on the national level and institutional needs at the local level, and illuminate the potentials for ideologically loaded policy processes caused by conflicting activities.

This special issue expands on Brumfit's classification of functions of language in higher education by offering a cross section of the tensions caused by the political (in)visibility of language in higher education, and the implications of this to universities as national institutions. In this issue, Nordic higher education provides a testing ground for theorizing about the position of language in developments of internationalization and knowledge society, and of the position of national institutions within those developments. The articles discuss the position of language in developments of internationalization and globalization (Hellekjær and Fairway 2015; Fabricius et al. in this issue; Airey et al.), knowledge formation (Airey et al., see also Kuteeva and Airey 2014) and of the position of national institutions within those developments (Ljosland 2015; Saarinen and Taalas in this issue).

Methodologically, the presentation expands on existing views on how discourses of language, internationalization and knowledge society are operationalized in the social dynamics of higher education. The observation that higher education institutions are devising language policies with the dual role of safeguarding the national language(s) while institutionalizing the status of English as a de facto universal language of higher education, may be an indication of the strengthening or re- emergence of "national" as a critical factor in internationalization or globalization, exemplified by the role of institutional language policies in navigating between "national" and "international", and by the top-down mechanisms that the institutions have experienced as the major motivator for those policies (Saarinen and Taalas in this issue; Airey et al. in this issue). Empirically, focus on language makes hierarchies and paradoxes within internationalization visible. Language, thus, seems to be becoming politically visible, which has relevance for the questions of higher education as a national and international institution.

\section{References}

Airey, J. (2009). Science, Language and Literacy: Case studies of learning in Swedish university physics. Uppsala: Acta Universitatis Upsaliensis. 
Alexander, R. (2008). "International" programmes in the German speaking world and englishization: A critical analysis. In R. Wilkinson \& V. Zegers (Eds.), Realizing Content and Language Integration in Higher Education (pp. 77-95). Maastricht: Maastricht University Language Centre.

Anderson, B. (1991). Imagined communities. Reflections on the origin and spread of nationalism (2nd ed.). London: Verso.

Ball, S. (2012). Global education inc. New policy networks and the neo-liberal imaginary. London: Routledge.

Becher, T., \& Kogan, M. (1992). Process and structure in higher education. London: Routledge.

Becher, T., \& Trowler, P. (2001). Academic tribes and territories: Intellectual enquiry and the cultures of disciplines (2nd ed.). Buckingham: Open University Press/SRHE.

Blommaert, J. (2007). Sociolinguistic scales. Intercultural Pragmatics, 4(1), 1-19.

Brumfit, C. (2004). Language and higher education. Two current challenges. Arts and Humanities in Higher Education, 3(2), 163-173.

Byun, K., Chu, H., Kim, M., Park, I., Kim, S., \& Jung, J. (2011). English-medium teaching in Korean higher education: policy debates and reality. Higher Education, 62(4), 431-449.

Castells, M. (2000). The rise of the network society (2nd ed.). Oxford: Blackwell.

Clark, B. (1983). The higher education system. Academic organization in cross-national perspective. Berkeley: University of California Press.

Coleman, J. (2006). English-medium teaching in European higher education. Journal of Language Teaching, 39, 1-14.

Dale, R., \& Robertson, S. (2009). Beyond Methodological 'Isms' in comparative education in an era of globalisation. In R. Cowen \& A. M. Kazamias (Eds.), International handbook of comparative education (pp. 1113-1127). Dordrecht: Springer.

Fairclough, N. (1992). Discourse and social change. Cambridge: Polity Press.

Haapakorpi, A., \& Saarinen, T. (2014). Transnational turn and national models of higher education: The case of Finland. Nordic Studies in Education, 34(3), 187-200.

Halonen, M., Ihalainen, P., \& Saarinen, T. (2015). Diverse discourses in time and space. Historical, discourse analytical and ethnographic approaches to multi-sited language policy discourse. In M. Halonen, P. Ihalainen, \& T. Saarinen (Eds.), Language policies in Finland and Sweden: Interdisciplinary and multi-sited comparisons (pp. 3-26). Bristol: Multilingual Matters.

Hellekjær, G. O. (2010). Language matters: Assessing lecture comprehension in Norwegian English-medium higher education. In C. Dalton-Puffer, T. Nikula, \& U. Smit (Eds.), Language use and language learning in CLIL classrooms (pp. 233-258). Amsterdam: John Benjamins Publishing Company.

Hellekjær, G. O., \& Fairway, T. (2015). The mismatch between the unmet need for and supply of occupational English skills: An investigation of higher educated government staff in Norway. Higher Education, 70(6), 1033-1050.

Heller, M. (2011). Paths to Post-nationalism: A critical ethnography of language and identity. Oxford: Oxford University Press.

Hornberger, N. H., \& Johnson, D. C. (2007). Slicing the onion ethnographically: Layers and spaces in multilingual language education policy and practice. Special issue on Language Policies and TESOL: Perspectives from practice. TESOL Quarterly, 41(3), 509-532.

Hughes, R. (2008). Internationalisation of higher education and language policy: Questions of quality and equity. Higher Education Management and Policy, 20(1), 111-128.

Hult, F. (2010). Analysis of language policy discourses across the scales of space and time. International Journal of the Sociology of Language, 202, 7-24.

Kuteeva, M., \& Airey, J. (2014). Disciplinary differences in the use of English in higher education: Reflections on recent language policy developments. Higher Education, 67, 533-549.

Ljosland, R. (2015). Policymaking as a multi-layered activity. A case study from the higher education sector in Norway. Higher Education, 70(4), 611-627.

Marcus, G. (1995). Ethnography in/of the world system: The emergence of multi-sited ethnography. Annual Review of Anthropology, 24, 95-117.

Marginson, S. (2006). Dynamics of national and global competition in higher education. Higher Education, $52,1-39$.

Marginson, S., \& Rhoades, G. (2002). Beyond national states, markets, and systems of higher education: A glonacal agency heuristic. Higher Education, 43(3), 281-309.

Mortensen, J., \& Haberland, H. (2012). English: The new Latin of academia? Danish universities as a case. International Journal of the Sociology of Education, 216, 175-197.

Phillipson, R. (2009). Linguistic imperialism continued. New York and London: Routledge.

Saarinen, T. (2008). Persuasive presuppositions in OECD and EU higher education policy documents. Discourse Studies, 10(3), 341-359. 
Saarinen, T. (2012). Internationalization of Finnish higher education: Is language an issue? International Journal of the Sociology of Language, 216, 157-173.

Saarinen, T. (2014). Language ideologies in Finnish higher education in the national and international context: A historical and contemporary outlook. In A. K. Hultgren, F. Gregersen, \& J. Thøgersen (Eds.), English in Nordic Universities: Ideologies and practices (pp. 127-146). Amsterdam: John Benjamins. (Studies in World Language Problems (5)).

Saarinen, T. (2015). Policy as "wibbly-wobbly": Operationalizations of discourse as material action. In S. Jokila, J. Kallo, \& R. Rinne (Eds.), Comparing times and spaces. Historical, theoretical and methodological approaches to comparative education (pp. 109-125). Jyväskylä: Suomen Kasvatustieteellinen Seura ry. (Kasvatusalan tutkimuksia (69)).

Saarinen, T., \& Nikula, T. (2013). Implicit policy, invisible language: Policies and practices of international degree programmes in Finnish higher education. In A. Doiz, D. Lasagabaster, \& J. Sierra (Eds.), English-medium instruction at universities: Global challenges (pp. 131-150). Bristol: Multilingual Matters.

Saarinen, T., \& Ursin, J. (2012). Dominant and emerging approaches in the study of higher education policy change. Studies in Higher Education, 37(2), 143-156.

Saarinen, T., \& Välimaa, J. (2012). Change as an intellectual device and as an object of research. In B. Stensaker, J. Välimaa, \& C. Sarrico (Eds.), Managing reform in universities. The dynamics of culture, identity and organisational change (pp. 41-60). Basingstoke: Palgrave Macmillan.

Salö, L. (2010). Engelska eller svenska? En kartläggning av språksituationen inom högre utbildning och forskning. Rapporter från Språkrådet. Stockholm: Språkrådet.

Sherry, M., Thomas, P., \& Chui, W. H. (2010). International students: A vulnerable student population. Higher Education, 60(1), 33-46.

Teichler, U. (2005). Research on higher education in Europe. European Journal of Education, 40(4), 447-469.

Torres-Olave, B. M. (2012). Imaginative geographies: identity, difference, and English as the language of instruction in a Mexican university program. Higher Education, 63(3), 317-335.

Välimaa, J. (2005). Social dynamics of higher education reforms: The case of Finland. In Å. Gornitzka, M. Kogan, \& A. Amaral (Eds.), Reform and change in higher education (pp. 245-268). Dordrecht: Springer. (Higher Education Dynamics (8)).

Välimaa, J. (2008). Reflections on research questions, topics and themes identified during the HELF Project (Appendix 1). In J. Brennan, J. Enders, C. Musselin, U. Teichler, \& J. Välimaa (Eds.), Higher education looking forward: An agenda for future research (pp. 40-42). Strasbourg: European Science Foundation.

Välimaa, J. (2012). The corporatization of National Universities in Finland. In B. Pusser, K. Kempner, S. Marginson, \& I. Ordorika (Eds.), Universities and the public sphere. Knowledge creation and state building in the era of globalization (pp. 101-120). New York, London: Routledge.

Välimaa, J., \& Hoffman, D. (2008). Knowledge society discourse and higher education. Higher Education, $56(2), 265-285$.

Vertovec, S. (2007). Superdiversity and its implications. Ethnic and Racial Studies, 30(6), 1024-1054.

Williams, G. (2010). Knowledge economy, language and culture. Clevendon: Multilingual Matters. 